\title{
Assessing Consent through External Signs. Three Cases of Madness, Repulsion and Love before the Tribunal of the Roman Rota (1579-1619)
}

\author{
Isabelle Poutrin \\ Université de Reims Champagne-Ardenne, CERHIC (EA 2616), F-51100 Reims, France \\ Institut Universitaire de France \\ email : isabelle.poutrin@univ-reims.fr \\ ORCID iD: http://orcid.org/0000-0002-8182-0769
}

Submitted: 27 January 2017. Accepted: 7 July 2017

\begin{abstract}
How can it be assumed that an individual is incapable of giving consent or does not give it freely? This article analyses three cases handled by the Tribunal of the Roman Rota between 1579 and 1619: the case of a nun from the monastery of Odivelas (Portugal) suffering from mental disorders, and two demands for nullification of marriage based on the grounds of duress exerted by immediate family; the case of Doña Antonia Portocarrero y Cárdenas, of the diocese of Seville, married to Don Felipe de Guzman y Aragón; and the case of Manuel de Meneses and Branca de Baredo of the diocese of Coimbra. The testimonies on file relate the words and actions of the main parties involved, revealing affects and intentions. Auditors embarked on a complex operation to translate this information into the language of the law, in the light of legal experts' theories on individual responsibility and the nature of violence or constraints that may alter freedom of consent. Yet this also encompassed social practices and representations in which individual behaviours exist. This study illustrates the contrast between judges' know-how in assessing the absence of consent regarding marriage or religious profession and the fact that these notions were not taken into account regarding consent to baptism.
\end{abstract}

KEYWORDS: Justice; Marriage; Religious Profession; Canonical Law; Confession; Nobility; Medicine

Citation / Cómo citar este artículo: Poutrin, Isabelle (2017) “Assessing consent through external signs. Three cases of madness, repulsion and love before the Tribunal of the Roman Rota (1579-1619)". Culture \& History Digital Journal, 6 (2): e014. doi: http://dx.doi.org/10.3989/chdj.2017.014

RESUMEN: Evaluar el consentimiento a través de signos externos. Tres casos de locura, repulsa y amor ante el Tribunal de la Rota Romana (1579-1619).- ¿Cómo puede concluirse que un individuo es incapaz de dar su consentimiento o que no lo da libremente? Este artículo analiza tres casos tratados por el Tribunal de la Rota Romana entre 1579 y 1619: el caso de una monja del monasterio de Odivelas (Portugal) que padecía trastornos mentales, y dos demandas de nulidad de matrimonio motivadas por la coacción ejercida por la familia inmediata; el caso de Doña Antonia Portocarrero y Cárdenas, de la diócesis de Sevilla, casada con Don Felipe de Guzmán y Aragón; y el caso de Manuel de Meneses y Branca de Baredo, de la diócesis de Coimbra. Los testimonios registrados relatan las palabras y acciones de las partes implicadas, revelando afectos e intenciones. En estos procesos, los auditores emprendieron una compleja operación de traducción de dicha información al lenguaje legal, apoyándose en el ejemplo de expertos juristas y sus teorías sobre la responsabilidad individual y la naturaleza del tipo de violencia o coacción necesaria para alterar el libre consentimiento. Sin embargo, es necesario tener en cuenta que estas situaciones abarcaban también las prácticas sociales y representaciones en las que todo comportamiento individual se ven inmerso. Este estudio ilustra el contraste entre la pericia de los jueces a la hora de evaluar la ausencia de consentimiento en relación al matrimonio o la profesión de fe, y el hecho de que estas nociones no eran tenidas en cuenta a la hora de estimar el consentimiento para el bautismo.

PALABRAS CLAVE: Justicia; Matrimonio ; Profesión Religiosa; Ley Canónica; Confesión; Nobleza; Medicina

Copyright: (C) 2017 CSIC. This is an open-access article distributed under the terms of the Creative Commons Attribution License (CC BY) Spain 3.0. 
Since consent involves the intimate dimension of the individual, his ability to deliberate independently, and his capacity for self-reliance, it provides an excellent insight into the shaping of self-consciousness in the $16^{\text {th }}$ and $17^{\text {th }}$ centuries. To enter into this subject, to use the various ego-documents ${ }^{1}$, which address individual subjectivity in all its complexity, appears necessary. On the contrary, however, I propose considering the question of consent from the point of view of the authorities of the Catholic Church, and using legal sources. For the Church, individual consent was an important question which has given rise to many theoretical reflections and practical case studies. According to Catholic theology, consent is necessary for baptism, marriage, and the ordination of priests, as well as for religious profession. The starting point of the present study, which follows a previous research on the forced conversion of Muslims and Moriscos in $16^{\text {th }}$ century $\mathrm{Spain}^{2}$, is the hypothesis that, at that time, canonical law allowed two conceptions of consent to coexist (to baptism on one hand, to marriage and religious vows on the other hand), in which the place given to individual interiority was dramatically different. Consent to baptism was regulated according to standards originating in the forced conversion of the Jews under Visigoth King Sisebut in the $7^{\text {th }}$ century, and consolidated in the context of the persecution of the Jews in Western Europe in the last centuries of Middle Ages. Based on the principle that "forced consent is consent" (coacta voluntas, voluntas est), doctors (theologians and canonists) considered that individual consent was effective, and that baptism was therefore valid, as long as the individual did not expressly and vociferously demonstrate his refusal to be baptized. Pressures, threats and physical violence were not the recommended means of obtaining conversions, but they were not strictly prohibited either; followed by princes, the Church accepted the results ${ }^{3}$. If reception of baptism was in principle to be preceded by a period of instruction, the conversions carried out during the riots against Jews and Muslims, especially in Spain from the end of the $14^{\text {th }}$ century, were considered valid even though verification of consent was reduced to its simplest expression: acquiescence, even silence, in response to the priest's question "Wilt thou be baptized?" conversos and the Moriscos largely entailed the disjunction between the canonical norm, which received them under the jurisdiction of the Church and required them to observe its practices even when their consent had been extorted, and their private sentiments, which refused this forced membership. The regime of consent to baptism was thus characterised by its harsh view of the individual's true aspirations. For centuries, the desire to integrate "infidels" into the Church had taken priority over the question of the sincerity of their adherence to the Christian faith ${ }^{5}$.

At the end of the $16^{\text {th }}$ century, this canonical heritage seemed increasingly irreconcilable with another approach of consent, that which tended to prevail for marriage and religious profession, and will be the focus of our attention in this study. The Council of Trent does not mention the question of consent to baptism or priestly ordination, but it paid great attention to individual consent regarding marriage and entry into religion, which directly concerned the lives of families. While the Lutherans rejected the sacramental character of marriage and, to avoid clandestine marriages, extended the notion of consent to parents and the community, the Council of Trent recalled that the validity of marriage rests solely on the voluntary mutual consent of man and woman; it was therefore exempted from parental control - even if the Tametsi Decree $\left(24^{\text {th }}\right.$ session, c. 1$)$ made legal forms for the publicity of marriage compulsory ${ }^{6}$. On the other hand, in order to reaffirm the value of consecrated life and, in particular, of the contemplative life of women, the Council cast anathemas against those who forced a woman to enter the monastery, receive the habit or pronounce her vows $\left(25^{\text {th }}\right.$ Session, c.18). The affirmation of these principles stemmed from a theology which considered that consecrated life and, to a lesser extent, marriage were states of life capable of leading to salvation. In practice, their application raised many difficulties which were mainly related to verification of consent.

In marriage and religious profession, consent was expressed by words and then ratified by acts, that is, respectively, fleshly consecration of the union of spouses and observance of the monastic rule. The free will of the individual could therefore be deployed in a sacramental and ritualised act, and then for the duration of the couple's union or life in the convent. However, lack of consent was a ground to nullify the sacrament or a religious profession. The women and men concerned could appeal to the ecclesiastical courts under certain conditions in order to obtain recognition that their freedom had not been respected, and that they had been subjected to violence or pressure. If the court recognised that these acts had been such as to impair freedom of consent, the marriage or profession was declared null and void, and the applicant was released from any relationship with his spouse or with the religious community. Although covering only local situations, recent works suggest that numerous proceedings are kept in the archives of the ecclesiastical courts for the $16^{\text {th }}-18^{\text {th }}$ centuries, and that judicial conflict associated with this issue of freedom of consent was significant ${ }^{7}$.

How can it be assumed that an individual is incapable of giving consent or does not give it freely? What I propose here is to see how the Tribunal of the Sacred Roman Rota tackled this question, and to what extent it endeavoured to expose the depths of consciences in responding to demands for annulment of religious profession or marriage. This pontifical court judged on appeal civil cases, many of which about the benefits of the Church; a lesser number concerned the validity of religious vows or marriage $^{8}$. In the $17^{\text {th }}$ century, most of these cases came from Italy, Spain and Portugal, sometimes from Lorraine or Poland. Gallican France did not resort to this Tribunal, the incarnation of Roman authority. Due to the cost of the proceedings, the parties (excepting the Roman ones) were usually members of the social elites. Without pre- 
senting the Rota in detail ${ }^{9}$, it should be emphasised that it derived its immense prestige and great authority from its proximity to the Pope and the quality of its judges, an international college of twelve Auditors renowned for their competence and integrity as legal experts. Each case was entrusted by a letter from the Pope or the Vice-Chancellor to one of the Auditors, who became the rapporteur (ponente) thereof. With the help of his assistants, the rapporteur would examine the file prepared by both parties, that translated the facts into the language of the law. Then, during one of the court sittings which took place about twice a week from October to the beginning of July, he would propose to the four Auditors sitting on his left (his corresponsales) a question (dubium) relating to the merits of the case or a procedural issue. These Auditors replied in the affirmative or negative by a vote. When the different aspects of the case had been carefully discussed, the Rota produced a decision which could be considered definitive and acceptable for both parties. This last decision, then, was converted into a sentence that confirmed or rejected the judgement given in first instance. The losing party could still seek a review of the decision by the Rota itself, under the supervision of another rapporteur. With the exception of the Auditors' deliberations, which were not public, proceedings were written without any physical contact between the Auditors and the parties or the witnesses, and without any adversarial debate. Both parties' lawyers contacted the court with briefs presenting arguments in favour of their client. At the request of one of the parties, the Rota could grant approval to conduct an inquiry at the place of the dispute with witnesses. The testimonies collected by the local judge for the Roman Rota were then filtered by lawyers and formatted for use as evidence ${ }^{10}$. Thus, the proceedings kept the parties at a distance - a distance both geographical and symbolic in nature.

In the second half of the $16^{\text {th }}$ century, the Auditors began publishing, in the form of large volumes, collections of decisions issued on cases where they had been rapporteurs. These collections, circulated at Catholic level, were to serve in the training of diocesan judges in particular who heard cases of forced marriages and forced vocations at first instance. The apparatus surrounding the text of the decisions clearly shows that they were to help to build case law. Each decision is easily identifiable by an indication of the place of the case, the matter dealt with and the date of issue of the decision. It is preceded by a summary which brings successive points of the text back to principles of universally applicable law. The facts are heavily summarised. Nominative information is rare, sometimes absent, with the exception of straightforward first names. Witnesses are usually designated by numbers, and testimonies are reduced to a few significant sentences. The Roman Rota's decisions thus offer the historian highly abstract and stylised material, much more austere than documentation kept on file in the diocesan tribunals.

To determinate the validity of consent to marriage or religious profession, Auditors tried to trace the genealo- gy of each case by establishing the overall situational context. Documentation also contains evidence which is more subtle, but once gathered, completes the family histories: acts, words and writings that refer to the family intimacy of noble circles. All such information is translated into the language of law; the facts are filtered and interpreted to support the judicial decision. I shall first analyse a case of madness, which raises the problem of impaired capacity for consent. I shall then examine two cases of marriage that raise the issue of unauthorised consent.

\section{IMPAIRED CONSCIOUSNESS}

On 22 June 1579, the Auditors examined the case of a Portuguese nun, Margarida, whose brother, Luis Alvares, contested the validity of her profession on the grounds that she was mad. The opposing party, Antonio Telles, took the opposite view in arguing that Margarida's mental state had enabled her to declare her vows in a valid manner. The family history is not clear. I shall confine myself to the very brief information noted in the decision of the Rota. Margarida came from an aristocratic family. It is evidenced by the conditions of her admission to the Franciscan monastery of Nossa Senhora da Esperança in Lisbon, through the intervention of the superior, CardinalInfante Henri, who became King of Portugal in 1578. As the Franciscans had refused to admit her to the profession after her novitiate, she had entered the Cistercian monastery of São Dinis de Odivelas, a house near Lisbon inhabited by about a hundred nuns, most of them daughters of the high Portuguese nobility. Obviously, some members of her family wanted to see Margarida kept in a cloister and used their social influence for this purpose. They were able to mobilise Cardinal-Infante Henry before placing her with the Cistercians after the failure to join the Franciscans. There they managed to have the novitiate reduced to three days instead of the obligatory year, in spite of the Abbess's reluctance to receive a woman who in her words was notoriously mad and who had been refused by La Esperança for this reason. Between the two chapters of religious life, it seems that Margarida's brother had considered marrying her and that her mental state was considered dangerous for the family's good repute. When the case reached the Roman Rota, the profession at Odivelas already dated back several years. It would take another two meetings, in May 1580, to finally settle the case.

Where the Auditors had difficulty was in characterising the nun's disorderly conduct based on the testimonies on file. Without being constantly delirious and agitated (furiosam), she was still lacking in sanity. Her behaviour defined her reputation in both institutions for she was considered "insane and demented" (insana et demente) and "idiotic" (stulta). She said that she was unwell from a hair, that a face would appear to her in a hole, that she saw a Moorish magician, and that she didn't know whether she was going to commune, wash her hands or recite the Prime Office. Moreover, 
She went to the choir in her shirt [...]. She would smear her face with mud saying that she was doing it because her nostrils were very bright. [...] She would sweep the house with the sleeves of her tunic [...]. She would put her excrement on a stick and eat it [...]. She would urinate in a basket she showed to everybody [...]. She would throw her habit into the latrines [...]. She would throw her habit and her coat $[\ldots]$. She often laughed for no reason. $[\ldots]$ She would put raw meat in her nose and food inside her sleeve. [...] She would shout in hours of silence. ${ }^{11}$

The case was submitted to two doctors who discussed it with other colleagues and whose testimony is admitted in evidence. Moreover, after interviewing her, two Jesuits declared her incapable of confessing and receiving the other sacraments requiring the use of reason. A Cistercian monk confirmed this opinion: instead of kneeling and confessing, Margarita spat and mocked the nuns. Two notaries sent by the Ordinary of Lisbon echoed these individuals' assessment; they declared that she didn't even know her own name ${ }^{12}$.

Margarida's case is an example of impaired consciousness locked in an inner world to which documentation affords us no access. We can only observe her from the outside, in the strangeness of her actions. Her behaviour should have been a source of trouble for other nuns and disrupted the observance of rules, but testimonies show no reactions on the community's part other than rumours about her madness. It does not seem that the nuns laughed at her or were afraid of her ${ }^{13}$. There is no anguish in witness statements. None of them makes the slightest allusion to a supernatural cause behind Margarida's state. They do not contemplate the possibility of demonic possession or, conversely, of an excess of penitential fervour. It is a far cry from the "madness of the Cross" brought out by the Christian mysticism of the Renaissance ${ }^{14}$. Margarida's repugnant acts could not be included in the register of extreme penitential practices which were practiced in certain convents. In order to afflict their senses, certain descalced Spanish Carmelites willingly ate the vermin of spoiled food or the sputum of the sick, or disfigured themselves by rubbing their faces with waste ${ }^{15}$. These penances, however extreme, were nevertheless relatively codified and avoided scatology; they belonged to a conventual framework which was not that of the Cistercian nobles of Odivelas but that of a spiritual elite dedicated to the Catholic Reformation, and they fell within an internally consistent understanding of sanctity and sin.

In fact, even in the descriptions given by witnesses, Margarida's madness is fully grasped by law, described and understood from legal notions. The clinical picture appears only through this filter. Even before presenting a summary of testimonies, Francesco Cantucci of Perugia, the rapporteur for this case, stresses the difficulty of this case and raises the question of evidence of mental disorders:

As a matter of fact, although rage or dementia is invisible, for it cannot be perceived by the bodily senses but by judgment of the intellect (even if it exists in reality), to prove it, an insightful investigation is consequently required because witnesses can easily make mistakes and should not be believed unless they justify their assertions. ${ }^{16}$

The Auditors' mission was to determine Margarida's legal capacity, in this case her capacity to vow perpetual commitment to obedience, chastity and poverty. The use of reason was indeed an absolute necessity for the free exercise of consent and the creation of the irrevocable binding obligation between the nun and the community or the order that welcomed her ${ }^{17}$. Roman law had already established a difference between madness punctuated by periods of clear-sightedness and permanent madness. The madman (furiosus) was seized upon by the law precisely because he was incapable of managing his property or contracting any obligation and, being potentially dangerous to others, he had to be protected by a guardian. Only permanent madness brought about the furiosus's irresponsibility, since he was never able to manifest his will. On the contrary, he who was mad only occasionally could retain legal responsibility linked to these intervals of lucidity $^{18}$. The Auditors therefore had to strive to identify madness correctly. This required a complex operation whereby the subject's words and actions were observed and then interpreted and classified into categories set by lawyers. "Outward signs indicate the secrets of the soul," proclaimed the medieval commentators of Roman law ${ }^{19}$. Cantucci recalls examples of signs of dementia given by doctors: talking laughingly, throwing stones, throwing oneself into the sea, no longer knowing one's own name or what one does or doesn't want, and being incapable of articulate speech. Gestures or verbal expressions, actions which are not necessarily signs of madness in themselves, become so when they form a whole, completed by reputation: he "whom all commonly consider mad or insane is a madman"20.

Physicians' opinion was not decisive; it was weighed up among a series of conjectures and signs. At a time when psychopathology did not exist, the practice of forensic medicine remained subordinate to the authority of legal experts. While Paolo Zacchia, the author of Questiones medico-legales (1621-1651), may be considered to have liberated forensic medicine from the hegemony of lawyers, it must be emphasised that Zacchia places great emphasis on the Roman Rota's decisions among the authorities he drew upon. In his appendix, he published a hundred decisions and those of Auditor Cantucci concerning the profession of Margarida are among the first in the corpus ${ }^{21}$. In the creation of a semiology of madness, legal experts came before medical examiners ${ }^{22}$.

For the Auditors of the Rota, the opinion of the two Jesuits and the Cistercian carried much more authority than that of physicians. These priests had accompanied Margarida in the examination of her own conscience to prepare herself for confession, and had found her incapable of doing so. They were in the best position to know whether she was capable of discerning good and evil, an ability without which an individual was not responsible 
for his actions. Since the $12^{\text {th }}$ century, the Church had distinguished two scenarios in which individual acts were examined: the external forum, that is the courts where the justice of men resolved disputes and judged crimes and offences; and the internal forum or forum of conscience, where the priest, in confession, judged sins before God and imposed penances ordained for reparation and salvation. An entire store of knowledge had developed with the rise of the sacrament of penance; it circulated in the Tridentine period in the textbooks of confessors, collections of cases of conscience and treatises on moral theology. But the forum of conscience was not considered the place of inner monologue, of the free flight of intimate thoughts. It was defined as the space of consciousness as judged by an external eye, God, represented by the confessor. The judicialisation of the forum of conscience is the hallmark of this period ${ }^{23}$. The internal forum, like the judicial one, presupposed the free exercise of the subject's will. Yet the madman remained detached from himself; he could neither judge his own actions nor govern his conduct. According to these notions, it is logical that confessors should be considered more qualified than physicians to evaluate Margarida's mental state.

Despite this accumulation of concordant data, the Auditors advanced cautiously. The objections of the opposing party, who contested Margarida's madness in order to keep her in the monastery, needed still to be resisted. According to this other series of testimonies, she was able to read, sew and paint when she was at La Esperança, which may indicate that her mental derangement was only intermittent, and that she had thus been able to pronounce her vows in a valid manner. However, the Auditors responded that it was impossible to conclude that the nun was clearheaded at intervals from a discontinuous vision of separate actions: this would entail establishing that her mental health had been maintained over an extended period. Nor was the fact that Margarida pronounced the three canonical vows like any other nun decisive proof of her mental health. What ultimately carried the decision of the Rota was the general picture. They placed together the statements of experts (priests and physicians) and what was known about her words and gestures, but also the anomalies of her curriculum, her dismissal by La Esperança and her hurried novitiate at Odivelas. Furthermore, while Margarita's behaviour was pathological, her family embodied rationality for they wanted to save the lineage's good reputation and release it from a cumbersome burden by locking the young woman in a convent. Eventually, it seems that it was the doggedness of her family that secured the Auditors' conviction offering them clear proof of Margarita's madness.

\section{STORIES OF LOVE AND REPULSION}

Demands for annulment of marriage based on the ground of fear also led the Auditors to scrutinise the feelings and wishes of individuals. Under the influence of fear, an individual could act against his inner desire, conceal his feelings, and mask his refusal and grief under the guise of satisfaction and joy. Fear muddied the waters. As the famous canonist Balde de Ubaldis remarked in the $14^{\text {th }}$ century,

The will subjected to fear is, in a sense, in gestation; impure, it mixes disagreement with consent, and sometimes with a negative assertion. Indeed, it has a facade of consent, but internally a refusal, so that the heart of man is divided into two parts whereby one wants and the other refuses; the first manifests on the surface, the second is reality. ${ }^{24}$

However, in the canonical approach of consent to marriage, the saying "constrained consent is consent" did not apply. On the contrary, consent was to be freely given by man and woman, otherwise the sacrament was considered null. Judges were thus invited to discern the real will of the individual, under affected consent. However, I shall show here that the truth which arose from examining the case was judicial truth, that which the court established from signs and conjectures in the inability to penetrate consciences and hearts. I shall analyse two cases which reflect very contrasting situations.

In 1607-1609, the Roman Rota studied the demand of one individual referred to in the documents as "the Marquise of Alcalá", doña Antonia Portocarrero y Cardenas. Married to don Felipe de Guzman y Aragón when she wanted to marry don Francisco de Zuñiga, she filed a claim for the annulment of her marriage on the grounds that she had married for fear of her father. Alessandro Ludovisi of Bologna, Auditor of the Rota since 1599 who in 1621 became Pope Gregory XV, was the rapporteur of the case. He restored part of the family history, but only what was necessary for the work of the Tribunal. The six decisions he drafted in this case overlook the names and functions of the main parties involved, as well as the substance of political and financial issues surrounding the marriage. They do not say why don Pedro López Portocarrero, $1^{\text {st }}$ Marquis of Alcalá de la Alameda, wanted to unite his heiress Antonia to the second son of the $7^{\text {th }}$ Duke of Medina Sidonia, while the girl had (apparently) given her heart to don Francisco de Zuñiga, the eldest son of the $1^{\text {st }}$ Marquis of Villamanrique. Antonia's deceased mother, doña Elvira de Cardenas y Toledo, was the heir of don Gómez de Cardenas y Figueroa de Toledo, $2^{\text {nd }}$ lord of Lobón. On the other hand, the evidence on file tells us that during the marriage negotiations, Antonia tried to pass on a letter to Francisco written in her own hand, where she pledged to marry him while lamenting that she had to marry Felipe. However, the paper fell into her father's hands who flew into a terrible rage, to the point that Antonia denied writing it. Don Pedro (again according to testimonies) threatened to disinherit his daughter, or almost: he could not deprive her of the majorat established by his ancestors, but he could content himself with transferring this majorat as it was without the substantial increase he had planned. To these paternal threats was added pressure from Antonia's mother-in-law, doña Francisca Enríquez de Gúzman, and a priest known by the family. 
Separated from her usual confessor, the young heiress was kept under guard in her father's home and even prevented from going to church. She had, however, found a way to ask the Archbishop of Seville (don Rodrigo de Castro) for a brief from the apostolic nuncio prohibiting marriage. Far from helping him, the archbishop, a friend of her father's, had exhorted her to submit, making himself complicit in unauthorised consent. The sacrament was finally celebrated at night, behind closed doors, and by proxy in order to expedite the case's conclusion. After this, Antonia was taken from Seville to the castle of Coria for the consummation of the marriage.

This Sevillian case represented a situation well known to the Auditors of the Rota and ecclesiastical judges more generally: that of a young girl (sometimes a young man) whose family (often the father, but this could be the brother, the mother or even the grandmother) pushed into marrying or entering into religion for various reasons which all sacrificed the individual to the group. These included building an alliance with a prestigious family, optimising the use of the house's financial resources and increasing its honour by entering one of its members into a reputed religious establishment ${ }^{25}$. The Auditors' objective was to know the Marquise's state of mind (animus), when procedure did not allow them to question her directly. As was their wont, they had to rely on testimonies gathered from relatives by both parties. As in the case of Margari$\mathrm{da}$, the document allows us to approach Antonia's interiority through categories of law only, but it nevertheless also uses the language of feelings. The emotion she felt about her marriage to Felipe was "repulsion and repugnance"; her state of mind was "foreign and contrary" to this union. The signs of this repugnance were, according to witnesses, "the continual complaints and protests" with which she swore never to marry Felipe ${ }^{26}$. It is not certain that she was in love with Francisco or even wished to marry him because, according to some witnesses, she hadn't written her letter so much to marry Francisco as to try to escape the marriage with Felipe. We do not know the cause of her deep aversion towards this marriage: was Felipe ugly or disagreeable? Would she, her parents' only heiress, prefer to marry the elder of a lineage and not a junior, were he even the son of the richest man among the Great of Spain? These questions were not relevant to the work of the Rota Auditors. There is another series of indications about Antonia's feelings during the marriage she complained and said she was married against her will - and afterwards: "the great sadness and inconsolable affliction shown by the Marquise, her tears and the loud cries she uttered while driving her from Seville to the castle of Coria to ratify the marriage, so that she was disfigured by sadness and forced them all to weep with her" ${ }^{27}$.

Our third case, Coimbra's marriage, was fraught with disputes. Six successive decisions between December 1614 and March 1618 gave precise information. The rapporteur of this Portuguese case was Matteo Buratto of Bologna and a successor of Ludovisi to the Rota. Little is said of the plaintiff (actor), Manuel, except that his only income amounted to 600 ducats, derived from profits of the military order of Saint-Lazare. His lover Branca (his adversary before the Rota), widowed by two successive husbands, had two already adolescent sons, Antonio and Francisco, as well as a girl presented in documents only through her husband Filipe. One can therefore surmise that Branca was more or less over forty, and that Filipe was older than his brothers-in-law because he appears as the leader of the group. Manuel and Branca had had an affair that led them to get engaged. The engagement had been celebrated at night before some servants, at Branca's house in Assafarge, a town near Coimbra. Discretion was necessary because this engagement and, moreover, the marriage risked Manuel losing his ecclesiastical income. Manuel had, however, submitted a request to the Roman Curia to consolidate this possession and be able to marry. This prudent plan was thwarted by Branca's sons and son-in-law, who harboured strong hostility towards Manuel.

The wedding scene is reported in detail. On the eve of San Sebastián (on the evening of 19 January; the year is not specified), Blanca sent a servant to Manuel, in Coimbra, asking him to come as a matter of urgency. Once he arrived at his mistress's, and then found himself naked in bed with her, he looked on as Antonio, Francisco, and Filipe appeared accompanied by male and female servants. Filipe was armed with a sword and a harquebus. The three men demanded that Manuel marry his mistress immediately, and for this reason they summoned the parish priest on the pretext that Branca was seriously ill. Notwithstanding his entreaties to postpone the marriage in order to preserve his income from the Church, Manuel had to comply immediately on Filipe's orders. In the early morning, Manuel left the house to go to his friends and to the Bishop of Coimbra (don Alfonso de Castelo Branco), before bringing the matter before the judge of Formosinha and alleging that the marriage had been forced upon him through fear. Auditor Buratto's decisions still mentioned the inequality of wealth (despite equality of nobility) and the difference in age between Manuel and Blanca, and the doubt the groom's lawyers tried to instill about Blanca's good behaviour after the betrothal - but the Rota refused to authorise an on-the-spot investigation to verify this last allegation.

This affair concerned a noble widow who openly maintained a loving connection with a man which was not prepared to marry her. As he invoked his financial position so as to avoid marriage, she arranged to enforce it. The testimonies record the affects of the various main parties unevenly. Branca is the defendant, but there is no direct evidence of her feelings. In the fourteen letters written by Manuel, which are on record, Auditor Buratto had carefully counted seven instances of Branca's beauty being praised, but her only recorded words are those of the engagement vows with Manuel. Witnesses on her behalf reported that she provided for Manuel's food and welfare on a daily basis, behaving according to was, at this time, expected of a devoted wife. When Manuel had issued her his dimissorial letters (documents necessary for the receipt of religious orders), she had torn and 
burned them, which according to Buratto indicated that Manuel no longer intended to enter the orders. The Auditors did not examine the hypothesis that Branca, by destroying these papers, cut off any possibility of renouncing he whom she and all the servants considered her husband ${ }^{28}$. However, the Auditors suspected Branca and the young men of her family were complicit in the trap laid for Manuel: as the door of the room was not locked, it seemed likely that she had facilitated her son-in-law's and sons' entry. It was also she who suggested that Filipe tell the parish priest "that she was ill and ask to confess so that he would come more readily. ${ }^{29}$ " The three men's motives were clear: they wanted to defend Branca's honour and, through her, their own honour by compelling the lover to marry his mistress. In their eyes, Branca did not have free control over her body. Her affair with Manuel was to be consecrated by marriage. Their prevailing sentiment was at first "enmity" towards Manuel - they refused to greet him and talk to him - and then "anger and indignation" when they intruded into the room.

The file is centered on Manuel's affects because three of the man's feelings were decisive for the judicial settlement of the case: his love for Branca, the fear experienced at the time of the marriage, and then the anger that led him to reject this union. From the passionate love letters from Manuel to Branca, lawyers coldly extracted all passages which proved that the relationship was strong and that it was solemnised in a pledge of marriage:

In the second and tenth [letter], he says he is her husband, and Branca his wife. In the fourth, he still has the thirst, the appetite, and the desire to be in Branca's arms, where he hopes to live and die, etc., which is the only thing he always asks of God; and at the end he says that he will never cease to be her lover and husband. In the sixth, he prays that God might preserve Branca in the constancy she has often promised and sworn to him: which corroborates the witnesses' testimony on the engagement vows. ${ }^{30}$

In the Auditors' eyes, Manuel's fear that fateful night arose from circumstances: naked in bed, he was threatened by angry armed men. He stuttered his way through his marriage vows, to the point that Filipe had to order him to articulate correctly. Finally, he remained silent when the parish priest asked the spouses if they were happy after the exchange of the words of consent to marriage, and he left the house "in a bad mood."

The Rota's proceedings did not provide further insight into how the feelings, emotions and intentions of the main parties were directly expressed. It was nevertheless necessary to expose them because the case, as in the Marquise of Alcalá's one, is centred on the notion of fear (metus). If Antonia and Manuel had consented to marriage through fear and not freely, it must have resulted in the sacrament being null and void. However, although fear is classically defined by lawyers as "mental agitation" (mentis trepidatio) at the idea of a present or future danger $^{31}$, the Auditors did not analyse this emotion in its psychic and physiological effects, but only to show that the individual's capacity to give free consent had been altered. Fear had gripped Antonia when her father discovered her letter to Francisco, and, in order to placate her father's fury, had led her to lie, to say that she had not written this letter; fear clasped Manuel's throat and stifled his voice when he uttered the vows "I take you as my wife...". For the Auditors, Antonia's denials and Manuel's mumblings were signs that they translated into the language of the law.

\section{EVIDENCE OF CONSTRAINT}

The fear in question here is in fact a concept rooted in Roman canonical law. Experienced by an individual, it is associated with the violence committed by a third party of which fear is the result. In Roman law, constraint and fear (vis et metus) could bring about a claim for restitution, provided that fear is "such that it affects a stable man" (cadens in constantem virum), that is to say, an adult male individual of average mental and physical strength, and neither cowardly nor particularly heroic. It was against what the typical man could bear that judges assessed, on a case-by-case basis, whether the plaintiff could resist pressure and violence. Developed in the Digest, this notion was taken up in canonical law to the point that one title of the Decretals of Gregory IX (X.1.40) was dedicated to it. Judges exercised their arbitration power to assess whether the fear was justified, and therefore whether the resulting act was valid or vitiated. They examined the circumstances, the individual's ability to resist, the capacity of whoever inflicted fear to cause harm, and the type of constraint used (threats, blows, pressures, intimidation) ${ }^{32}$. After the Council of Trent, canonists endeavoured to organise and coordinate the law of the Church and comment on and disseminate standards stemming from the Council $^{33}$. They gave new focus to the question of consent and all the problems associated with the notion of fear. In 1600 in Seville, Baltasar Mogollón, a jurist from Caceres, published the first systematic treatise devoted to fear in its legal sense ${ }^{34}$ - a very austere work that Auditor Buratto mentions in one of his decisions on the case of Coimbra $^{35}$, and was republished in 1623. Mogollón's work was followed by the treatise of Antonio Cabreros Avendaño ${ }^{36}$, dedicated to the Duke of Olivares. The Madrilenian Cabreros Avendaño also undertook to define fear in a methodical way but mobilised a large body of literary sources from Antiquity, which opened up his book to a wider audience than Mogollón's. Despite the interest in Mogollón's book, the treatise De Sancto Matrimonio of Jesuit Tomás Sánchez of Cordoba, published in 1602 (with fourteen editions in the following half century), and of which Book 4 dealt with forced consent, quickly became the reference on the subject ${ }^{37}$. The provisions of the Council of Trent concerning the freedom of consent of nuns also simulated reflection on fear and constraint, which were grounds on which women and girls could challenge the validity of their religious profession. The Manuale Praelatorum regularium, by the Franciscan Luis Miranda, is an example ${ }^{38}$. Moreover, forced profes- 
sion concerned men, as evidenced by the collection of legal advice issued by the famous canonist Martin de Azpilcueta "Navarro", notably in the last stage of his career in Rome between 1567 and $1586^{39}$. In the extensive literature on legal advice (consilia), it is precisely here where questions concerning acts committed under duress and factors tainting freedom of consent developed remarkably during this period.

In this field, it seems that the decisions of the Roman Rota have played a major role in consolidating doctrine and resolving various issues. The decisions of Auditor Ludovisi in the case of the Marquise of Alcalá show that it was not simply a matter of resolving a specific case, but also of providing the canonists with a solid theoretical foundation on the relationship between consent and constraint. The fifty-point summary of decision 326 of 18 June 1607 declares that Ludovisi uses the marchioness' case to provide a systematic presentation on the theme of fear, dealing with the difficulties and means of providing evidence of constraint, the specific features of reverential fear (as defined below), the principles by which judges should assess levels of constraint, the circumstances that might presuppose the exercise of constraint, and the number and quality of witnesses admitted into the system of evidence $^{40}$. Ludovisi continued with decision 352 of 28 January 1608 which dealt with the quality of eligible witnesses in proving that a marriage had been granted under duress $^{41}$. Decision 374 of 23 June 1608 provided information on the evidence and conjecture which could prove constraint had been imposed and the difficult problem of the level of constraint from which it could be assumed a woman in particular had consented out of fear ${ }^{42}$. The principal theme of decision 392 of 15 December 1608 was the "purging" of fear, that is to say, the interval beyond which it could be presumed that constraint ceased to be exercised, and that the individual had thus regained the capacity to express his consent freely. The summary set out the principle whereby judges should assume that constraint was at play as long as the person who inflicted it was still alive; there was therefore no fixed time limit. This provision removed any appearance based probative value which might imply that the individual under duress had finally accepted the situation: "As long as the cause of fear persists, whatever he might do, even if he demonstrates his free consent and his happy and joyous mood, fear cannot be deemed to be purged" ${ }^{43}$. In the decision of 26 January 1609, Ludovisi posited the equally essential principle that a nullified marriage could not be validated $a$ posteriori by a simple agreement or "ratification", but had to be celebrated in all the forms required by the Council of Trent: this meant that forced marriage was considered completely null and void ${ }^{44}$. Finally, the last decision in the series, number 414 dated 5 June 1609, set out the grounds on which the Auditors refused a remissoria, that is, the authorisation to conduct a further investigation on the site of the dispute. In this case, Felipe had called for further investigation in the hope of delaying the trial; he also alleged that he had not been kept informed of the Marquise's legal action ${ }^{45}$. This decision was impor- tant for it added to the case law of the Rota. This served to postpone one of the parties' ultimate delaying tactics at a time when a case had already been the subject of several deliberations and was approaching its conclusion.

To a lesser extent, Auditor Buratto also regulated the matter of fear and constraint in a systematic way. Thus, Filipe's armed entry into the room where Manuel and Blanca lay gives rise to three normative statements in the summary of decision 213: "The terror of weapons arouses the just fear of death or corporal punishment. The fear generated by the terror of weapons does not subside even if they are not used or put down, as long as they can be easily taken up again. The fear produced by the terror of weapons is highly conductive to annulling a marriage" ${ }^{46}$. This point had already been addressed by Tomás Sánchez, who affirmed that the terror of weapons is a fear "such that it affects a stable man" even if those who carry them did not make use of them ${ }^{47}$; likewise, Ludovisi had stressed that the armed servants' presence at the time of marriage was likely to frighten the Marquise ${ }^{48}$. Buratto mentioned these two texts in his own development and, in turn, helped to consolidate jurisprudence on this point. The mere presence of weapons, without direct assault or threat, could be invoked before the Rota to request the annulment of a marriage.

The major issue raised by the Marquise of Alcalá's case was that of so-called "reverential fear" (metus reverentialis) as a ground for annulling the marriage. Mogollón had not defined what reverence was, but gave a general norm ("reverence is due to every superior") ${ }^{49}$, and then set out specific cases: a wife owes reverence to her husband, a son to his father and mother, descendants to their ascendants, a servant to his master, a youth to his elders, etc. If reverence was manifested generally by an attitude of respect, in certain cases it also included the possibility of receiving punishment as the husband, father, master or abbot possessed the right to correct their wife, children, servants, students or monks. Reverential fear, thus, was instilled by a superior to an inferior, by virtue of this power of constraint. Mogollón referred to the doctors' debate on the effects of reverential fear, understood as a ground for judicial action: was a superior's mere presence sufficient to instill "just fear" (that is, fear affecting freedom of consent) or should it be accompanied by threats and blows? His own opinion was that the mere presence of the person instilling fear was sufficient for the other one to invoke this ground (otherwise, threats and blows had to be invoked), especially if the following conditions were met: the act concerned two persons bound by an obligation of reverence, for example a girl who was about to be married and lived with her father; the individual instilling fear was known to threaten or strike his inferiors; the damage committed was extremely serious. Mogollón concluded that reverential fear could be legitimately invoked by men and women, even in spiritual cases (thus religious profession); and that it was thus an impediment to free consent, so that tacit consent given in the presence of whoever instilled reverential fear could be appealed ${ }^{50}$. Sánchez's conclusions were less clear-cut. 
The Jesuit tended to consider that reverential fear was not enough to amount to constraint "such that it affects a stable man" if not accompanied by threats and blows ${ }^{51}$. Nevertheless, he encouraged careful consideration of the circumstances, the character of the father and of the child, and the intensity and repetition of the pressures exerted ${ }^{52}$. For the Rota, the Marquise of Alcalá's affair combined the classic features of reverential fear which, as the Auditors found decisive, included Antonia's complaints and protests. While there was no question of death threats or serious ill-treatment, the Auditors felt that a woman was more likely to be frightened than a man, and that it was enough that the fear be "such that it affects a stable woman". They used the possibility opened by Sánchez of taking into account reverential fear even if not accompanied by threats or blows. The marriage of doña Antonia Portocarrero y Cardenas with don Felipe de Guzmán y Aragón was annulled, which allowed her to marry don Pedro Girón de Ribera in 1611. It may therefore be considered that this case's outcome was a decisive step in taking into account the will of young people and, consequently, that the Roman Rota thus showed its willingness to put a limit on the strategic alliances of heads of aristocratic houses findings that our research in progress, more specifically focused on the sociological aspect of this episode, will put to the test.

In the Portuguese case, it was a question of whether the Tribunal could consider that the marriage had been contracted under duress when Manuel was the lover of Branca and even her fiancé, as his letters and testimonies showed. In this type of "marriage by force" (matrimonium meticulosum), the man usually held a higher social position than the woman, and promised to marry her for her to consent to sexual intercourse; the woman's family managed to catch the two lovers in the act, if necessary by setting a trap for the seducer; the aim was to safeguard family honour ${ }^{53}$. Between marriage and the threat of a vengeful death, the man chose the first outcome as a lesser evil. The requirement of free consent, laid down by canonical law, then allowed him to contest the validity of the commitment thus contracted. He then had to prove before the judges that the constraint he had experienced was "such that it affects a stable man", which implied that he had been in imminent danger of death or injury, that he had been confronted by persons who were genuinely menacing in their attitude or character, that he had had no opportunity to flee, and that he had exhibited real terror ${ }^{54}$. Coimbra's case was thus atypical in terms of the profile of the main parties involved, their respective ages and their social positions.

Legal theories on consent and constraint, as well as the Rota's previous decisions concerning similar cases, provided the lens through which the Auditors read extracts of testimonies and arguments presented by both parties. Thus the Marquis of Alcalá is presented as terrible, hard and irascible in character, and therefore capable of frightening his daughter. What does it matter that other witnesses described him as an ordinarily placid man? Antonia's lawyers presented him as a man who would be- come angry when contradicted ${ }^{55}$. A father and Castilian nobleman such as the Marquis was certainly accustomed to being obeyed unswervingly and exercising his right of correction over his dependents; one can especially assume that he was eager to realise his plan to marry his heiress to the Duke of Medina Sidonia's youngest. However, the Auditors were not interested in the Marquis's plans and did not seek to know more about who the man was. The essential point was that the Marquis described by the witnesses corresponds to the model of severe, rigid, authoritarian and angry father or husband, ready to execute his threats, which are found in other cases judged by the Rota and other tribunals ${ }^{56}$. Lawyers sometimes had to adjust the content of testimonies or the requirements of provisional arguments. Thus, in general, the threat of deprivation of property could be seen as pressure to impair freedom of consent; but the Marquise was in no danger of suffering from hunger and poverty, for her father could only threaten not to increase her majorat since he had no power to change the rules for conferring it. This threat was, however, used as evidence by the Marquise's lawyers ${ }^{57}$, who portrayed the opposition between respectful, fearful girl deprived of any means of appeal, and her imperious, menacing father seconded by the insistent pressures of her stepmother ${ }^{58}$. Similarly, the Portuguese case showed a man frightened by three angry men bursting into the room where he lay naked in bed with his mistress, a typical picture of matrimonium meticulosum. All the same, one clearly sees that Manuel, despite his fear, had maintained composure to ask for a delay in evoking his ecclesiastical benefits, that the next day he went to explore the legal remedies against his marriage with a beautiful, rich, honourable and beloved woman, and that he had been careful not to set foot in her house so that no one could claim that the fear had been "purged". Finally, what convinced the Auditors were not only Manuel's "great repulsion" of marrying in these unpleasant circumstances but also the length of the legal proceedings, first in Portugal, then in Rome for four long years, his obstinacy in asking for the marriage to be annulled and, in addition, the age difference with his mistress. Without particularly examining Manuel's intimate feelings, the Auditors thought it unlikely that he wanted to marry her. At this point, only the archival documents give the key of the story. According to one of Branca's lawyers, Manuel de Meneses had met Branca de Baredo as he had come to negotiate with her the marriage between Filipe de Sousa, his grandson, and the widow's daughter, Francisca Dessa. "But after the conclusion of the marriage, he, Don Manuel, remained captive of his love for Branca and began to speak about marrying her." ${ }^{59}$ According to the criteria of the time, the difference of age was acceptable when the woman was much younger than the husband, but not when she was his grandson's mother-in-law.

There is an adage by the canonists which goes "the Church does not adjudicate hidden matters" ${ }^{60}$. The Auditors of the Rota could only adjudicate on the basis of signs suggesting the absence or refusal of consent, pressure and threat. To this end, they had to translate into 
signs words of varying degrees of explicitness (complaints and protests), but also objects (weapons), the circumstances of time (the night, the passing of years) and place (a closed room), bodily manifestations (tears, stammering and sighing, pallor, hardening of the face) and a whole series of actions which, in isolation, would not have been significant but which, when connected to each other, made up a story. With this information, the Auditors exposed a truth which nonetheless remained probable rather than absolutely certain. In other words, documentation of the Rota provides no window on the secret of hearts and neither reveals the depths of consciences which is beside its purpose. It is therefore fascinating to study the way in which the Tribunal approached the question of consent from outside that intimate part of individuals. Moreover, the judicial perspective remained closed in on itself. Therefore, nor do the Rota's decisions assist in understanding the strategies of the main parties involved as social actors, or in realising the stakes involved in the three cases analysed here respecting the heritages, reputation and social trajectory of the families concerned $^{61}$. On the other hand, one cannot help but be struck by the contrast between the two approaches of consent referred to at the beginning of this article. In the area of baptism and conversion, the theological and legal principles prohibited any procedure for the verification a posteriori of consent and any possibility of reversal, so that judges' know-how in building evidence based on words, circumstances and bodily language was not used to study cases of forced baptism and pronounce their annulment, but to detect the heretical and deviant behaviour of converts and their descendants.

\section{ACKNOWLEDGEMENT}

This research has been founded by the Centre de recherche en histoire européenne comparée (CRHEC, EA 4392) of Université Paris-Est Créteil (UPEC) and by the Institut universitaire de France (IUF).

\section{NOTES}

1 Dekker (2002)

2 Poutrin (2012)

3 (Marmursztejn, 2016; Poutrin, 2012).

4 (Benítez Sanchez-Blanco, 2001; Poutrin, 2012).

5 In a vast bibliography, see (Paiva, 2010; Nirenberg, 2014; Poutrin, 2015; Marmursztejn, 2016; Madunic, 2017).

6 (Bernard, 1980); Harrington, 1995: 98).

7 For marriage, see (Cazzetta, 1999; Seidel Menchi and Quaglioni, 2000; Feci, 2005; Cristellon, 2010). For religious profession: see (Diefendorf, 1996; Schutte, 2011; Roger, 2013).

8 Work on this tribunal remains limited. The complexity of cases and the often aristocratic origins of the parties concerned lend themselves well to specific case studies: Noonan (1972). Other approaches are possible, such as a study of proceedings for matrimonial matters, also involving handwritten documentation: (Feci, 2005; Fosi, 2011).

9 (Hoberg, 1994; Flaiani, 2009).

10 (Flaiani, 2009: IX-XII).

11 « Secundo probatur ex pluribus facis et gestis clare dementiam, et insaniam ostendentibus, quia ibat ad chorum in camisia;
[...] implebat faciem luto, dicendo se ideo ita facere, quia nares sibi multum fulgebant; [...] verrebat domum mantica tunicae ; [...] ponebat excrementa narium in uno baculo, et postea illa comedebat; [...] urinabat in una parria, et illa publice omnibus ostendebat; [...] proiiciebat cucullam in latrinis; [...] proiicebat cucullam et habitum; [...] ridebat saepe saepius sine proposito; [...] ponebat carnem crudam in sinu et cibum in mantica; [...] vociferabatur tempore silentii $»$, (Bordoni, 1665: 498).

12 (Bordoni, 1665: 498).

13 On these reactions to madness, see (Carrera, 2010a: 6; Carrera, 2010b; Lopez Poza, 2006).

14 (Foucault, 1972: 42-43).

15 (Roullet, 2015: 92-101, 233).

16 «Nam licet furor sive dementia sit quid invisibile, quod non sensu coporis, sed iudicio intellectus percipitur, etiamsi in facto consistat, et propterea in eius probationes perspicax inquisitio requiritur, quia teste facile possunt errare et ideo eis non creditur, nisi causam sui dicto manifestam faciant », (Bordoni, 1665: 497).

17 (Bordoni, 1665: 290)

18 Vallar (2016)

19 « Exteriora indicant secreta animi », (Boari, 1983: 32).

20 « Furor ostenditur in eo qui... communiter ab omnibus reputatur pro furioso vel demente », (Bordoni, 1665: 498; Boari, 1983: 60-71).

21 (Zacchia, 1621: 143-146, 147-148). On Zacchia (1621); Pastore and Rossi (2008).

22 (Boari, 1983: 14).

23 (Turrini, 1991; Prodi, 2001).

24 "Est enim meticulosa voluntas, praegenerans, impura, et multiplicans quendam dissensum cum consensu, et quandam cum affirmative negationem; habet enim in superficie volitionem, in medulla nolitionem, et scinditur cor hominis in duas partes, et una pars est velle, altera non velle; prima superficialis, secunda realis $»$, (Balde de Ubaldis, 1615: 120).

25 For examples of forced marriages in Venice, see (Cristellon, 2010: 241-248); on matrimonial strategies in the Spanish aristocracy, see (Soria Mesa, 2007: 115-212).

26 (Ludovisi, 1622: 353).

27 « Apertissime demonstrant maxima tristitia, et inconsolabilis afflictio, qua Marchionissa afficiebatur, ploratus et maximi clamores quos emittebat, dum ex civitate Hispalensi duceretur ad oppidum de Coria ad ratificandum matrimonium, ita ut ipsa prae nimia tristitia facta fuisset valde difformis, et omnes cogeret a collachrymandum », (Ludovisi, 1622: 357).

28 (Buratto, 1660: 177-178).

29 «Et illico vocatus fuit Parochus de ordine Philippi, suggerente Blancha, ut ei diceretur, qui illa aegrotabat, et confessionem petebat, ut facilius veniret $»$, (Buratto, 1660: 101).

30 "In secunda, et decima profitetur et nominat se maritum, et Blancham uxorem. In quarta dicit, habere semper eandem sitim, appetitum, et desiderium, esse in brachis Blanchae, in quibus sperat vivere et mori, etc., quod hoc est solum, quod semper a Deo petiturus est; et in fine dicit, quod nunquam futurum erat, ut desineret esse illius amator et maritus. In sexta Deum rogat, ut Blancham conservet in firmitate, quam totiens illi promisit et juravit: quod multum coadjuvat depositionem supradictum testium super juramento sponsalium », (Buratto, 1660: 177).

31 Digeste, 4.2.1.

32 Marchetto (2001)

33 (Fantappiè, 2008: 17-30).

34 Mogollón (1600).

35 (Buratto, 1660: 103).

36 Cabreros Avendaño (1634).

37 Tomás Sánchez, Disputationum de sancto matrimonio, Genuae, apud Iosephum Pavonem (1602: 681-816). For further readings on Sánchez, see Alfieri (2010); on Sánchez and consent, see (Noonan, 1972: 31-40).

38 (Miranda, 1612: 168-169).

39 Martin de Azpilcueta Navarro (1600); for a biographical survey of Navarro, see Lavenia (2003).

40 (Ludovisi, 1622: 352). 
41 (Ludovisi, 1622: 387).

42 (Ludovisi, 1622: 414).

43 "Quamdiu enim durat causa metus, quicumque actus fiat, etiamsi praeferat liberam voluntatem et laetum, jucundum animum, nedum metum non purgat », (Ludovisi, 1622: 433-434).

44 (Ludovisi, 1622: 435).

45 (Ludovisi, 1622: 457-458).

46 « Metum justum mortis, vel corporis cruciatus, inducit armorum terror. Metus incussus ex armorum terrore non cessat ex illorum non usu, imo neque ex depositione, quando de facili reassumi possunt. Metus incussus ex armorum terrore plurimum operatur ad matrimonium annullandum », (Buratto, 1660: 263).

47 (Sánchez, 1602: 699).

48 (Ludovisi, 1622: 444).

49 «Genericè dico, quod quilibet superiori debetur reverentia », (Mogollón, 1600: 59).

50 (Mogollón, 1600: 68-79).

51 (Sánchez, 1602: 708).

52 Marchetto (2006).

53 See, for instance, (Cristellon, 2010: 254-246).

54 For a case in 15th century Verona, see Marchetto (2001).

55 (Ludovisi, 1622: 354).

56 Marchetto (2006)

57 (Ludovisi, 1622: 355).

58 (Ludivisi, 1622: 414-415).

59 «Cum D. Emanuel de Meneses ad tractando matrimonium pro D. Philippo de Sousa eius nepote cum D. Branca de Baredo vidua pro D. Francisca Dessa filia sua [...] matrimonium conclusum fuit, ipse D. Emanuel remansit captus amore d. D. Brancha et tractavit eam in uxore ducere ", Archivio di Stato di Roma, S. Rota Romana, vol. 1242, s.f.

60 Chiffoleau (2006).

61 Our current research aims, precisely, to study different cases regarding constraint and consent in their multiple dimensions, using legal literature as well as archival documents. This paper presents the first results of this work.

\section{REFERENCES}

Alfieri, Fernanda (2010) Nella camera degli sposi. Tomás Sánchez, il matrimonio, la sessualità (secoli XVI-XVIII). Il Mulino, Bologna.

Balde de Ubaldis (1615) In Sextum Codicis Librum Commentaria. Haeredes Georgii Varisci, Venice.

Benítez Sánchez-Blanco, Rafael (2001) Heroicas decisiones. La Monarquía Católica y los moriscos valencianos. Institucio Alfons el Magnanim, Diputacion de Valencia, Valencia.

Bernard, Jean (1980) "'Le décret Tametsi du Concile de Trente: triomphe du consensualisme matrimonial ou l'institution de la forme solennelle du mariage". Revue de droit canonique, 30: 209-233.

Boari, Marco (1983) Qui venit contra iura. Il furiosus nella criminalistia dei secoli XV e XVI. Giuffré, Milano.

Bordoni, Francesco (1665) "Tractatus de professione regulari". Operum tomus Quintus, quo continetur Praxis Criminalis et Tractatus de professione regulari. Apud Ioannis-Antonii $\mathrm{Hu}-$ guetan et Marci-Antonii Ravaud, Lyon.

Buratto, Matteo (1660) Decisiones cum annotationibus eruditissimis D. Ioan Francisci Ferentilii, t. 1. Sumptibus Ioannis-Antonii Huguetan et Marci-Antonii Ravaud, Lyon.

Cabreros Avendaño, Antonio (1634) Methodica delineatio de Metu omnibus tam Iuris quam Theologiae Professoribus utiliter praescripta, et ad prime necessaria. Apud Franciscum Martinez, Madrid.

Carrera, Elena (2010a) "Madness and Melancholy in Sixteenth- and Seventeenth-century Spain: new evidence, new approaches". Bulletin of Spanish Studies: Hispanic Studies and Research on Spain, Portugal and Latin America, 87, 8: 1-16.

Carrera, Elena (2010b) "Understanding Mental Disturbance in Sixteenth- and Seventeenth-century Spain: medical approaches". Bulletin of Spanish Studies: Hispanic Studies and Research on Spain, Portugal and Latin America, 87, 8: 105-136.
Cazzetta, Giovanni (1999) Praesumitur seducta. Onestà e consenso femminile nella cultura giuridica moderna. Giuffrè, Milano.

Chiffoleau, Jacques (2006) " "Ecclesia de occultis non iudicat". L'Eglise, le secret, l'occulte au XVe siècle». Micrologus. Natura, scienze e società medievali, 14: 359-481.

Cristellon, Cecilia (2010) La carità e l'eros: Il matrimonio, la Chiesa, I suoi guidici nella Venezia del Rinascimento (1420-1545). Il Mulino, Bologna (english translation, 2017: Marriage, the Church and Its Judges in Renaissance Venice, 1420-1545. Palgrave Macmillan, New York.

Dekker, Rudolf, (editor) (2002) Egodocuments and History: Autobiographical Writing in its Social Context since the Middle Ages. Verloren, Hilversum.

Diefendorf, Barbara (1996) «"Give us back our children”. Patriarchal Authority and Parental Consent to Religious Vocations in Early Counter-Reformation France». Journal of Modern Histo$r y, 68,2: 265-307$.

Fantappiè, Carlo (2008) Chiesa e modernità giuridica, t. I, L'edificazione del sistema canonistico (1563-1903). Giuffrè, Milano.

Feci, Simona (2005) "Cause matrimoniali nella documentazione del tribunale della Sacra Romana Rota (secolo XVII)". Annali dell'Istituto storico-germanico in Trento, XXXI: 189-224.

Flaiani, Enrico (2009) Sacra Rota Romana. Processus Actorum, Indice 1247/1, buste 1-100. Archivio Vaticano, Città del Vaticano.

Fosi, Irene (2011) Papal Justice: Subjects and Courts in the Papal State 1500-1700. Catholic University of America Press, Washington D.C.

Foucault, Michel (1972) Histoire de la folie à l'âge classique. Gallimard, Paris.

Harrington, Joel F. (1995) Reordering Marriage and Society in Reformation Germany. Cambridge University Press, Cambridge.

Hoberg, Herman (1994) Inventario del Archivio della Sacra Rota Romana (sec. XIV-XIX) a cura di Josef Metzler. Archivio Vaticano, Città del Vaticano.

Lavenia, Vincenzo (2003) "Martin de Azpilcueta (1492-1586), un profilo". Archivio italiano per la storia della pietà, 16: 15-144.

Lopez Poza, Sagrario (2006) Amentes, dementes, stulti (representaciones de los privados de razon en el siglo de Oro), Follia, Follie. Universita degli Studi di Firenze, Alinea Editrice, Firenze.

Ludovisi, Alessandro (1622) Sacrae Rotae Romanae decisiones coram Alexandro Ludovisio nunc Sanctissimo Domino Nostro Gregorio $X V$. Typographia Reverendae Camerae Apostolicae, Rome.

Madunic, Domagoi (2017) "Conversion under the Threat of Arms: Converts and Renegades during the War for Crete (16451669)". In Conversion and Islam in the Early Modern Mediterranean World: The Lure of the Other, edited by Norton, Claire. Routledge, London: 30-49.

Marchetto, Giuliano (2001) "“Iustus est metus mortis et cruciatus corporis". Il matrimonium meticulosum in un consilium di Bartolomeo Cippola (ca. 1420-1475)». In Matrimoni in dubbio, unioni controverse e nozze clandestine in Italia dal XIV al XVIII secolo, edited by Seidel Menchi, Silvana, and Quaglioni, Diego, Il Mulino, Bologna: 247-278.

Marchetto, Giuliano (2006) "Il volto terribile del padre. "Metus reverentialis" e matrimonio nell'opera di Tomas Sánchez". In I tribunali del matrimonio, secoli XV-XVIII, edited by Seidel Menchi, Silvana and Quaglioni, Diego. Il Mulino, Bologna: 269-288.

Marmursztejn, Elsa (2016) Le Baptême forcé des enfants juifs: question scolastique, enjeu politique, échos contemporains. Les Belles Lettres, Paris.

Martin de Azpilcueta Navarro (1600) Consiliorum et responsorum libri quinque, juxta quinque libros et titulos Decretalium distincti. Apud Johannem Guerilium, Venice.

Miranda, Luis (1612) Manuale Praelatorum Regularium, primus tomus. Apud Bartholomaeum Zannettum, Rome.

Mogollón, Baltasar (1600) Tractatus de his quae vi, metusve causa fiunt. Apud Franciscum Rodriguez, Seville.

Nirenberg, David (2014) Neighboring Faiths. Christianity, Islam and Judaism in the Middle Ages and Today. The University of Chicago Press, Chicago. 
Noonan, John T. Jr. (1972) Power to dissolve: Lawyers and Marriage in the Courts of the Roman Curia. Belknap Press of Harvard University Press, Cambridge, Massachusetts.

Paiva, José Pedro (2010) "I vescovi portoghesi e il battesimo forzato degli Ebrei nel 1497'. Rivista di Storia del Cristianesimo, 1: $11-22$.

Pastore, Alessandro and Rossi, Giovanni [editors] (2008) Paolo Zacchia: alle origine della medicina legale (1584-1659). Franco Angeli, Milano.

Poutrin, Isabelle (2012) Convertir les musulmans. Espagne, 14911609. Puf, Paris.

Poutrin, Isabelle and Tallon, Alain [editors] (2015) Les expulsions de minorités religieuses dans l'Europe latine (XIIIe - XVIIe s.). Bière, Pompignac: 45-67.

Prodi, Paolo (2001) Una storia della giustizia: dal pluralismo dei fori al moderno dualismo tra conscienza e diritto. Il Mulino, Bologna.

Roger, Alexandra (2013) "Contester l'autorité parentale: les vocations religieuses forcées au XVIIIe siècle en France". Annales de démographie historique, 1, $125:$ 43-67
Roullet, Antoine (2015) Corps et pénitence Les carmélites déchaussées espagnoles (ca. 1560-ca. 1640). Casa de Velázquez, Madrid.

Sánchez, Tomás (1602) Disputationum de sancto matrimonio. Apud Iosephum Pavonem, Genova.

Schutte, Anne Jacobson (2011) By Fear and Force. Taking and Breaking Vows in Early Modern Europe. Cornell University Press, New York.

Seidel Menchi, Silvana, Quaglioni, Diego, [editors] (2000) Conjugi nemici: La separazione in Italia dal XII al XVIII secolo. Il Mulino, Bologna.

Soria Mesa, Enrique (2007) La nobleza española en la España moderna. Marcial Pons, Madrid.

Turrini, Myriam (1991) La coscienza e le leggi: Morale e diritto nei testi per la confessione della prima Età moderna. Il Mulino, Bologna.

Vallar, Sandrine (2016) Folie et droit romain - Quelques observations, Criminocorpus. Folie et justice de l'Antiquité à l'époque contemporaine. http://criminocorpus.revues.org/3146 [accessed 16/december/2016].

Zacchia, Paulo (1621) Questionum medico-legalium tomus primus. Anisson \& Joannis Posuel, Lyon. 